\title{
CHANGING TRENDS IN RISK FACTORS FOR CARCINOMA BREAST
}

\section{P. Rajagopal' ${ }^{1}$ P. Shanthini' ${ }^{2}$ A. S. Karthikeyan ${ }^{3}$, S. S. Abhinand ${ }^{4}$, D. Thangamani 5}

1 Professor, Department of Surgery, KAPV Government Medical College, Trichy.

2Professor, Department of Surgery, KAPV Government Medical College, Trichy.

${ }^{3}$ Postgraduate, Department of Surgery, KAPV Government Medical College, Trichy.

${ }^{4}$ Postgraduate, Department of Surgery, KAPV Government Medical College, Trichy.

5 Postgraduate, Department of Surgery, KAPV Government Medical College, Trichy.

ABSTRACT
BACKGROUND
Carcinoma breast is the world's most common cancer among females. In India, it is the leading cancer among women in cities
and second most common cancer in rural women. According to WHO, India has the highest incidence in the world.

\section{METHODS AND MATERIAL}

Data collection is a study of 95 cases of Cancer Breast diagnosed and treated at KAPV Government Medical College and Mahatma Gandhi Memorial Government Hospital, Tiruchirapalli, Tamilnadu.

\section{OBSERVATION}

The tumour size, axillary lymph node status, ER, PR, HER2-neu receptors and surgical margin positivity are the important prognostic indicators.

\section{CONCLUSION}

Hence, it concluded that for patients with breast cancer, the prognostic markers that can be routinely assessed are axillary lymph nodal status, tumour size, histological grading, oestrogen and progesterone receptor status, post-operative findings like positive margins. They are helpful in planning adjuvant treatment.

\section{KEYWORDS}

Lump in Breast, Axillary Lymph Node Status, Metastasis, Nottingham Prognostic Index in Carcinoma Breast.

HOW TO CITE THIS ARTICLE: Rajagopal P, Shanthini P, Karthikeyan AS, et al. Changing trends in risk factors for carcinoma breast. J. Evolution Med. Dent. Sci. 2016;5(75):5597-5602, DOI: 10.14260/jemds/2016/1263

\section{INTRODUCTION}

Carcinoma breast is the world's most common cancer among females. In India, it is the leading cancer among women in cities and second most common cancer in rural women. According to WHO, India has the highest incidence in the world.

Carcinoma breast is the leading cause of cancer related death in women all over the world. ${ }^{1}$ It is often regarded as cancer of rich, because it is more common in developed countries. $^{2}$ The reason can be attributed to late age of childbirth, less prevalence of lactation, high intake of fat rich diet. ${ }^{3}$ The early age of menarche, late menopause, nulliparity, radiation exposure, some genetic factors, increased age all implicated in the aetiology of breast cancer. ${ }^{4}$

Even though the breast cancer incidence has increased all over the world, the mortality remain stable due to increased use of mammogram screening and various treatment modalities like surgery, chemotherapy and radiation. ${ }^{5}$ One of the fact which is epidemiologically significant is increase in number of breast cancer among women less than 30 years.

Financial or Other, Competing Interest: None.

Submission 01-08-2016, Peer Review 06-09-2016,

Acceptance 12-09-2016, Published 19-09-2016.

Corresponding Author:

Dr. P. Rajagopal,

\#66, Nachiarpalayam,

Woraiyur,

Trichy - 620003.

E-mail:malaraja2009@yahoo.com

DOI: $10.14260 /$ jemds $/ 2016 / 1263$
These types of tumours are usually high-grade with lymphovascular invasion. ${ }^{6}$

Breast cancer, which is one of the most commonly diagnosed cancers in women is an epithelial malignancy of lobules or ducts. ${ }^{7}$ The metastatic dissemination of breast cancer cells contributes to the majority of death. ${ }^{8}$ The tenyear survival rate of patients with diffuse metastasis is only $9 \% .{ }^{9}$

The determination of receptor, especially in FNAC core needle biopsy specimen and post-operative biopsy specimen have important prognostic and survival benefit.10,11 The management also depend upon whether breast tissue express this receptor or not. ${ }^{12}$ The stage of tumour and axillary lymph node status are the most important prognostic factor in the breast carcinoma. ${ }^{13}$

Earlier the treatment of breast cancer was predominantly surgical; however, in the recent times the treatment plan of breast cancer changes completely with wider range of therapeutic options. Thus, it has become increasingly important to assess prognosis for each of these patient before a therapeutic suitable plan is chosen. ${ }^{14}$

The number of tumour-related features available to predict the prognosis of patients with breast cancer has grown impressively in recent years. Histology, tumour stage and lymph node status are now supplemented with measurements of steroid hormone receptors, ploidy, S-phase fractions, growth factors, oncogenes and oncogenic products. These cellular and molecular biological features have not only advanced the understanding of carcinogenesis, but have 
provided a host of new biologic measures potentially related to the clinical outcome.

The most important clinically relevant feature is familial breast cancer. They occur due to mutation in BRCA1 and BRCA2 gene mainly. BRCA1 situated in chromosome 17q and BRCA2 is situated in chromosome $13 \mathrm{q} .15$ The characteristic feature of this type of tumour are young age of onset, poorly differentiated tumour, highly multicentric and multifocal, high chance for bilateral involvement, associated ovarian cancer. ${ }^{16}$

\section{METHODS AND MATERIAL}

\section{Data Collection}

This is a study of 95 Cases of Cancer Breast diagnosed and treated at KAPV Government Medical College and Mahatma Gandhi Memorial Government Hospital, Tiruchirapalli, Tamilnadu.

\section{RESULTS AND OBSERVATIONS}

\section{Nottingham Prognostic Index in Carcinoma Breast (16)}

The Nottingham Prognostic Index (NPI) is used to determine prognosis following surgery for breast cancer. Its value is calculated using three pathological criteria: the size of the lesion, the number of involved nodes and the grade of the tumour.

\section{Calculation}

The index is calculated using the formula:

$$
\mathrm{NPI}=[0.2 \times \mathrm{S}]+\mathrm{N}+\mathrm{G}
$$

\section{Where:}

$\mathrm{S}$ is the size of the index lesion in centimetres

$\mathrm{N}$ is the node status: 0 nodes $=1,1-4$ nodes $=2,>4$ nodes $=3$

$\mathrm{G}$ is the grade of tumour: Grade I $=1$, Grade II $=2$, Grade III $=3$ 5-Year Survival Rate.

\begin{tabular}{|c|c|}
\hline Score & 5-Year Survival \\
\hline$>/=2.0$ to $</=2.4$ & $93 \%$ \\
\hline$>2.4$ to $</=3.4$ & $85 \%$ \\
\hline$>3.4$ to $</=5.4$ & $70 \%$ \\
\hline$>5.4$ & $50 \%$ \\
\hline \multicolumn{2}{|c}{ Table 1 } \\
\hline \multicolumn{2}{|c}{} \\
\hline
\end{tabular}

\section{Grading is Based on Three Histological Features}

1. The amount of gland formation ("differentiation" or how well the tumour cells try to recreate normal glands).

2. The nuclear features ("pleomorphism" or how "ugly" the tumour cells look).

3. The mitotic activity (how much the tumour cells are dividing).

Each of these features is scored from 1-3, and then each score is added to give a final total score ranging from 3-9. The final total score is used to determine the grade in the following way:

1. Grade 1 tumours have a score of 3-5.

2. Grade 2 tumours have a score of 6-7.

3. Grade 3 tumours have a score of 8-9.

Research Design: Prospective study.

Duration of Study: 5 years.
All histological proven cases of cancer breast were included in the study. Patient who are willing for surgery and followup are only included. All patients with above criteria with age group more than 20 years are included. Immunohistochemical studies of ER, PR receptors were done in all patients.

\section{Exclusion Criteria}

Patients operated and referred for further management from outside hospital were excluded from the study. Patient not willing for follow-up are excluded.

\section{RESULT AND INTERPRETATION}

Sex

Only $<1 \%$ of cases of cancer breast occurred in men. In our study, only two patients were male. Both had invasive intraductal carcinoma and were treated with modified radical mastectomy and adjuvant chemotherapy. They account for $2.10 \%$.

\section{Age}

Incidence of breast cancer increases with age. In U.S., lifetime risk of developing breast cancer is $12.2 \%$ or 1 in 8 women. The incidence of carcinoma breast adjusted for age shows increase in incidence occurred primarily in women aged 55 yrs. or older.

In our study, highest incidence was seen in age group of 40 to 50 yrs.

\section{Age Group}

\begin{tabular}{|c|c|c|}
\hline $\begin{array}{c}\text { Age Group } \\
\text { (Years) }\end{array}$ & $\begin{array}{c}\text { No. of Patients } \\
\text { (n=95) }\end{array}$ & $\begin{array}{c}\text { Percentage } \\
(\mathbf{1 0 0 \% )}\end{array}$ \\
\hline <30 years & 2 & 2.10 \\
\hline 30 to 40 years & 22 & 23.14 \\
\hline 40 to 50 years & 45 & 47.36 \\
\hline 50 to 60 years & 22 & 23.14 \\
\hline 60 to 70 years & 4 & 4.21 \\
\hline \multicolumn{3}{|c|}{ Table 2 } \\
\hline
\end{tabular}

\section{Family History}

Women with first degree relatives affected by carcinoma breast have a 1.7 to 2.5 relative risk of breast cancer development. About 5\% of breast cancers appear to have inherited gene mutations that are dominant and highly penetrant. In our study, there was no significant family history.

\section{Socio-Economic Status}

Cancer breast is more common in women of higher socioeconomic status, but in our study our patients belonged to lower socioeconomic status.

This can be explained by the fact that most of the people utilizing the health services of this institution are from lower socioeconomic group.

\section{Menstrual Status}

Increased exposure to endogenous oestrogen peaks during menstrual cycle and predisposes to carcinoma breast. For every year of delay in menarche, there is an apparent decreased risk of breast carcinoma by $20 \%$. Women with menopause after 55 years have twice the risk of developing 
carcinoma breast compared to women attaining natural menopause before 45 years.

In our study 3 patients attained menarche before age of 12 and 6 attained menopause after 55 years, 4 underwent total abdominal hysterectomy with bilateral salpingooophorectomy for coexisting gynaecological problems like dysfunctional uterine bleeding, fibroid:

- 45 patients were premenopausal, $47.36 \%$.

- 44 patents were postmenopausal, $46.31 \%$.

\section{Parity}

- Nulliparous women have a relative risk of about 1.4.

- In our study, 5 patients were nulliparous which was about $5.26 \%$.

\section{Age at First Pregnancy}

First full-term pregnancy after age 30 have a two-fold to fivefold increase in breast cancer risk compared with women having a first full-term pregnancy before age 18 or 19. In our study, only 9 patients had their first child above the age of 28 years.

\section{Lactation}

It is difficult to determine the beneficial effects of breast feeding, independent of pregnancy with regards to breast cancer. Some studies indicate that breast feeding for longer duration of time has a protective effect. In our study, only 3 patients had not breast fed their children.

\section{Clinical Presentation}

In our study, clinical presentation were as follows.

\section{Various Clinical Presentation}

\begin{tabular}{|c|c|c|}
\hline Particulars & $\begin{array}{c}\text { No. of Patients } \\
\text { (n=95) }\end{array}$ & $\begin{array}{c}\text { Percentage } \\
\text { (100\%) }\end{array}$ \\
\hline Painless lump & 52 & 54 \\
\hline Lump with pain & 24 & 25.24 \\
\hline Lump with ulcer & 3 & 3.14 \\
\hline Nipple discharge & 12 & 12.63 \\
\hline Metastatic symptoms & 4 & 4.21 \\
\hline \multicolumn{3}{|c|}{ Table 3 } \\
\hline
\end{tabular}

\section{Size of the Tumour}

\begin{tabular}{|c|c|c|c|}
\hline $\begin{array}{c}\text { Size in } \\
\text { (CMS) }\end{array}$ & $\begin{array}{c}\text { No. of } \\
\text { Patients } \\
\text { (n=95) }\end{array}$ & $\begin{array}{c}\text { Percentage } \\
(\mathbf{1 0 0 \% )}\end{array}$ & $\begin{array}{c}\text { Survival } \\
\text { Rate }\end{array}$ \\
\hline$<2$ & 6 & $15.83 \%$ & 100 \\
\hline 2 to 5 & 25 & $28 \%$ & 92 \\
\hline$>5$ & 64 & $71 \%$ & 76 \\
\hline \multicolumn{4}{|c|}{ Table 4 } \\
\hline
\end{tabular}

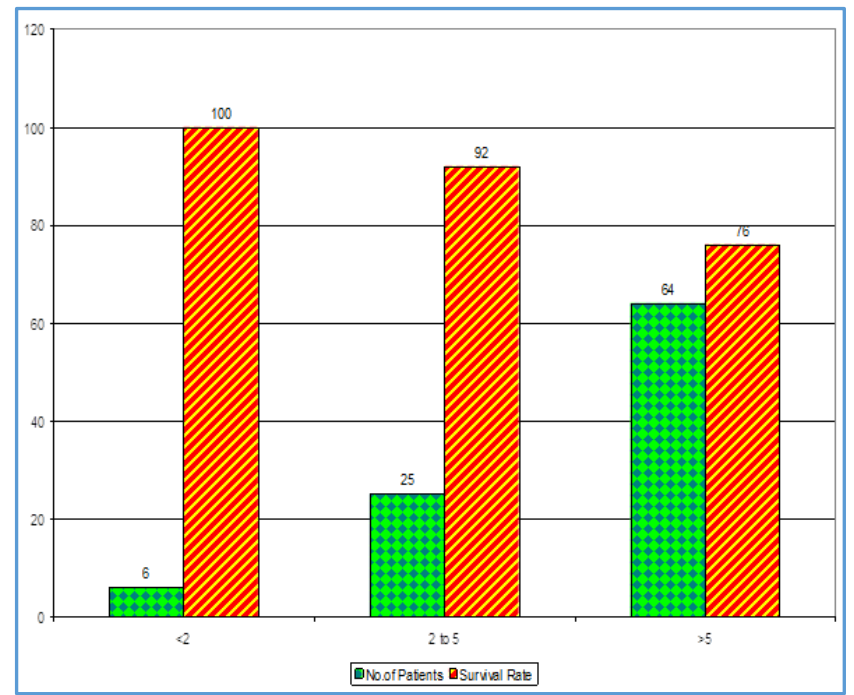

Fig. 1

Lymph Node Involvement in Relation to Survival Rates

\begin{tabular}{|c|c|c|c|}
\hline $\begin{array}{c}\text { No. of } \\
\text { Nodes }\end{array}$ & $\begin{array}{c}\text { No. of } \\
\text { Patients } \\
\text { (n=95) }\end{array}$ & $\begin{array}{c}\text { Percentage } \\
\mathbf{( 1 0 0 \% )}\end{array}$ & $\begin{array}{c}\text { 5 years } \\
\text { Survival }\end{array}$ \\
\hline Nil & 29 & $31 \%$ & $80 \%$ \\
\hline$<3$ & 54 & $57 \%$ & $50 \%$ \\
\hline$>3$ & 12 & $12 \%$ & $21 \%$ \\
\hline \multicolumn{4}{|c|}{ Table 5 } \\
\hline
\end{tabular}

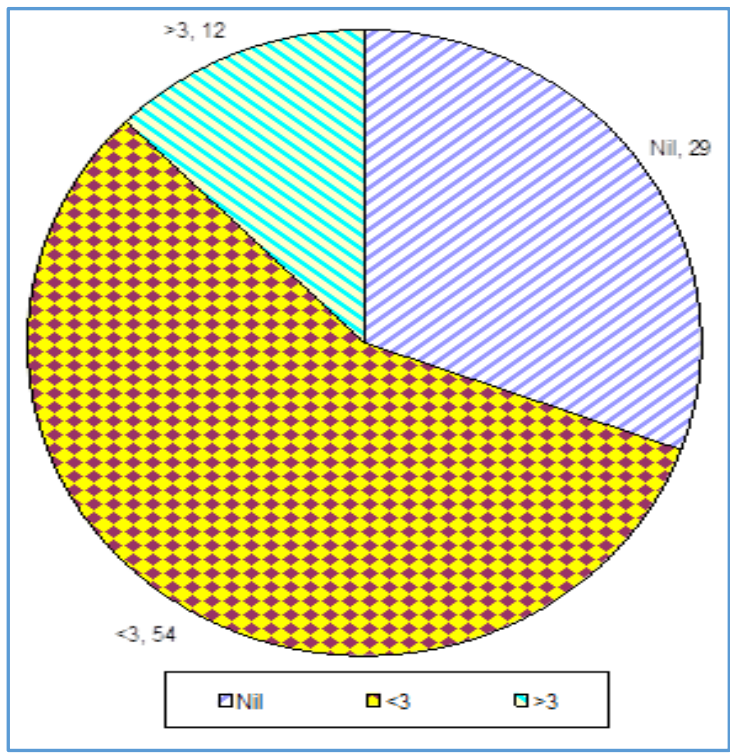

Fig. 2

Tumour Staging

\begin{tabular}{|c|c|c|}
\hline Stage & No. of Patients (n=95) & $\mathbf{( 1 0 0 \% )}$ \\
\hline I & 1 & 1.05 \\
\hline II A & 9 & 9.47 \\
\hline II B & 22 & 23.15 \\
\hline III A & 26 & 27.36 \\
\hline III B & 33 & 34.73 \\
\hline IV & 4 & 4.21 \\
\hline \multicolumn{3}{|c|}{ Table 6 } \\
\hline
\end{tabular}


Various Histopathological Types

\begin{tabular}{|c|c|c|}
\hline Type & $\begin{array}{c}\text { No. of Patients } \\
\text { (n=95) }\end{array}$ & $\mathbf{( 1 0 0 \% )}$ \\
\hline $\begin{array}{c}\text { Invasive ductal } \\
\text { carcinoma }\end{array}$ & 80 & $84.21 \%$ \\
\hline Ductal carcinoma in situ & 4 & $4.20 \%$ \\
\hline Lobular carcinoma & 2 & $2.10 \%$ \\
\hline Malignant Phyllodes & 1 & $1.05 \%$ \\
\hline Scirrhous type & 1 & $1.05 \%$ \\
\hline Colloid carcinoma & 1 & $1.05 \%$ \\
\hline Medullary carcinoma & 3 & $3.14 \%$ \\
\hline Papillary carcinoma & 1 & $1.05 \%$ \\
\hline Mucinous carcinoma & 1 & $1.05 \%$ \\
\hline Metaplastic carcinoma & 1 & $1.05 \%$ \\
\hline \multicolumn{2}{|l}{} \\
\hline
\end{tabular}

Histological Grading

\begin{tabular}{|c|c|c|c|}
\hline Grade & $\begin{array}{c}\text { No. of Patients } \\
\text { (n=84) }\end{array}$ & $\begin{array}{c}\text { Percentage } \\
(\mathbf{1 0 0 \% )}\end{array}$ & $\begin{array}{c}\text { Survival Rate } \\
\mathbf{5} \text { yrs. }\end{array}$ \\
\hline I & 42 & 53 & 90 \\
\hline II & 32 & 35 & 63 \\
\hline III & 10 & 12 & 47 \\
\hline \multicolumn{3}{|c|}{ Table 8 } \\
\hline
\end{tabular}

\section{HORMONE RECEPTORS}

ER Status in Relation to Age Groups $(n=95)$

\begin{tabular}{|c|c|c|c|}
\hline Age Group & $\begin{array}{c}\text { No. of } \\
\text { Patients } \\
\text { (n=95) }\end{array}$ & $\begin{array}{c}\text { No. of ER+ } \\
\text { Cases }\end{array}$ & $\begin{array}{c}\text { No. of ER- } \\
\text { Cases }\end{array}$ \\
\hline $\begin{array}{c}20 \text { to } 29 \\
\text { yrs. }\end{array}$ & 2 & 0 & 2 \\
\hline $\begin{array}{c}30 \text { to } 39 \\
\text { yrs. }\end{array}$ & 22 & 11 & 11 \\
\hline $\begin{array}{c}40 \text { to } 49 \\
\text { yrs. }\end{array}$ & 45 & 33 & 12 \\
\hline $\begin{array}{c}50 \text { to } 59 \\
\text { yrs. }\end{array}$ & 22 & 3 & 8 \\
\hline $\begin{array}{c}60 \text { to } 69 \\
\text { yrs. }\end{array}$ & 4 & \multicolumn{3}{|c|}{ Table 9 } \\
\hline Total & $\mathbf{9 5 ( 1 0 0 \% )}$ & $\mathbf{6 1 ( 6 5 \% )}$ & $\mathbf{3 4 ( 3 5 \% )}$ \\
\hline \multicolumn{4}{|c|}{} \\
\hline
\end{tabular}

PR Status in Relation to Age Groups (n=95)

\begin{tabular}{|c|c|c|c|}
\hline Age Group & $\begin{array}{c}\text { No. of } \\
\text { Patients } \\
\text { (n=95) }\end{array}$ & $\begin{array}{c}\text { No. of PR+ } \\
\text { Cases }\end{array}$ & $\begin{array}{c}\text { No. of PR- } \\
\text { Cases }\end{array}$ \\
\hline 20 to 29 yrs. & 2 & 0 & 2 \\
\hline 30 to 39 yrs. & 22 & 10 & 12 \\
\hline 40 to 49 yrs. & 45 & 30 & 15 \\
\hline 50 to 59 yrs. & 22 & 12 & 20 \\
\hline 60 to 69 yrs. & 4 & 2 & 2 \\
\hline Total & $\mathbf{9 5}$ & $\mathbf{5 4}$ & $\mathbf{4 1}$ \\
\hline \multicolumn{4}{|c|}{ Table 10 } \\
\hline
\end{tabular}

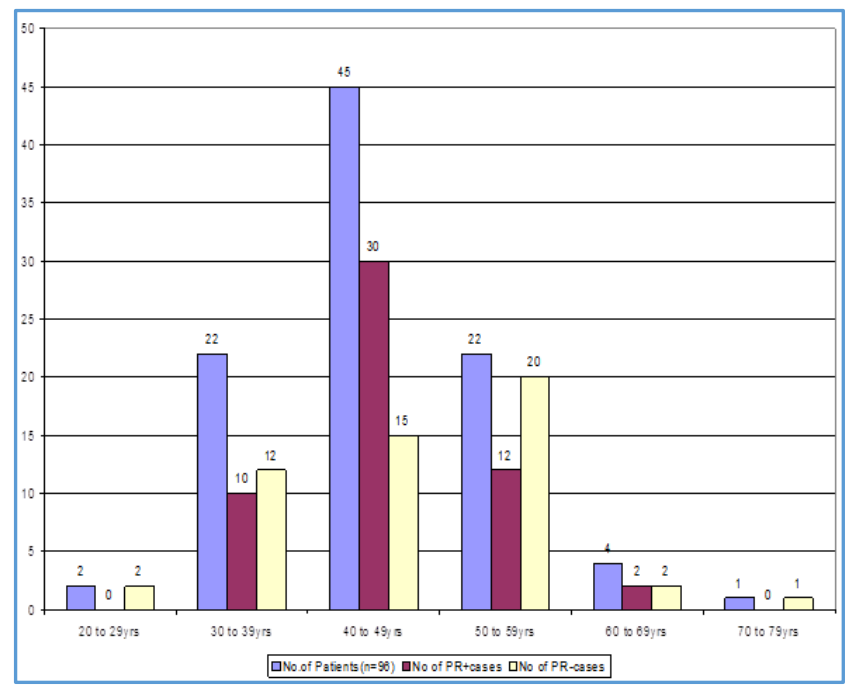

Fig. 3

Nottingham Prognostic Index

T-Size $(\mathrm{cms}) \times 0.2+$ Lymph node stage $(1-3)+$ Histological grade (1-3)

1 - No Node.

2 - Upto 3 Nodes.

3 - > 3 Nodes.

\begin{tabular}{|c|c|c|}
\hline NPI & Prognosis & 15 Years Survival \\
\hline$<3$ & Good & $80 \%$ \\
\hline 3.1 to 5.4 & Moderate & $42 \%$ \\
\hline$>5.4$ & Poor & $13 \%$ \\
\hline \multicolumn{3}{|c|}{ Table 11 } \\
\hline
\end{tabular}

In Our Study

$\begin{array}{lc}\text { NPI } & \text { No. of Patients } \\ <3 & 8 \\ 3.1-5.4 & 55 \\ >5.4 & 32\end{array}$

During our follow-up, it was detected that out of 32 patients with NPI $>5.4,5$ patients had local recurrence, 3 patients had lung metastasis, 2 patients had spine metastasis, 1 patient brain metastasis, 2 patients had supraclavicular node involvement.

\section{RESULTS AND OBSERVATIONS OF THE STUDY}

In Our Study, the following Observations were Made

1. The commonest age of presentation was $40-50$ years of age.

2. About 47.36 were premenopausal and 46.31 were postmenopausal, $5.26 \%$ were Nulliparous.

3. Commonest mode of presentation was painless lump in $46.31 \%$.

4. Most of the patients presented with stage III disease $62.09 \%$.

5. Lymph node positivity during presentation was about $69.46 \%$.

6. Invasive ductal carcinoma was the commonest pathological variety in our stage. Histological grade I was found in $56.84 \%$.

7. Most of our patients presented with Tumour size more than $5 \mathrm{~cm}(67.36 \%)$. 
8. Modified Radical mastectomy was done in 90 patients. Toilet mastectomy was done in 5 patients presenting with ulceration/fungating lesions.

9. Resected margins were found to be positive in 5 patients, all of them were given radiotherapy. Three of them developed locoregional recurrence, 2 developed metastasis. One in lung, one in brain.

10. Lymph node examination for metastatic deposits in pathological specimen showed positivity in 49 patients. More than 6 nodes were positive for metastatic deposits in 13 patients, of which 4 developed locoregional recurrence and one developed liver and lung metastasis. One patient with supraclavicular node developed spine metastasis. All patients were treated with chemotherapy and radiotherapy.

11. Histologic grade 1 found in 44.21 of patients, grade 3 found in $10.52 \%$ of our patients (10 Pts.) of which 3 had locoregional recurrence; 2 developed lung secondaries during the follow-up period.

12. Patients who developed lung metastasis had Tumour size more than $8 \mathrm{~cm}$ during presentation and 1 of them had histological grade III invasive ductal carcinoma. Supraclavicular node was involved in one patient.

13. One patient with brain metastasis had tumour size of 6 $\mathrm{cm}$ during presentation, she had more than 6 nodes positive for deposits in pathological resection specimen.

14. One patient who developed both spine and liver metastasis presented with tumour involving all quadrants.

15. In the hormone receptor study done in 95 cases, oestrogen receptor positivity was seen in $65 \%$, negativity for both receptors in 35\% with increase in positivity in older age group (50-59 years).

- ER+, PR- tumours are more prevalent in postmenopausal age group.

- Special histological variants like papillary carcinoma, lobular carcinoma are positive for ER and PR. Medullary and Metaplastic variants are negative for both receptors.

16. Nottingham Prognostic Index was found to have direct correlation with prognosis in our study. In 32 of our patients with NPI more than 5.4, 5 had local recurrence, 3 had lung metastasis, 2 developed spine metastasis and one developed brain metastasis during followup.

\section{DISCUSSION}

The aim of the study is to identify the prognostic factors in primary breast cancer. The utility of prognostic factors lies not only in their ability to prognosticate the outcome of the disease, but also in detecting early disease, monitoring the disease course, screening for recurrent disease. They also help in deciding upon administration of adjuvant systemic therapy and in identifying patients with poor prognosis who warrant more aggressive investigational therapies.

Commonly assessed prognostic factors are number of lymph nodes in the axilla, tumour size, TNM stage, histologic tumour type, histologic tumour grade. Immunohistochemical study of ER/PR hormone receptor in breast cancer patients will lead onto a precise and individualised management, which will have better impact on the disease free survival and overall survival rate. ${ }^{17}$
Tumour size has linear relationship with prognosis and eventual metastasis. As tumour size increased survival rate decreased regardless of lymph nodal status and as lymph node involvement increased survival status decreased regardless of tumour size. Medial lesions have slightly worse prognosis than lateral lesions due to involvement of internal mammary nodes.

Histological grading of tumour also seems to correlate with regional recurrence and metastasis. Patients with postoperative positive resection margins were also at high risk of locoregional recurrence. ${ }^{18}$

\section{CONCLUSION}

Hence, it concluded that for patients with breast cancer, the prognostic markers that can be routinely assessed are axillary lymph nodal status, tumour size, histological grading, oestrogen and progesterone receptor status, post-operative findings like positive margins. They are helpful in planning adjuvant treatment.

\section{REFERENCES}

1. Benson JR, Jatoi I. The global breast cancer burden. Future Oncol 2012;8(6):697-702.

2. Torre LA, Bray F, Siegel RL, et al. Global cancer statistics, 2012. CA: a cancer journal for clinicians. 2015;65(2):87108.

3. Calle EE, Rodriguez $\mathrm{C}$, Walker-Thurmond $\mathrm{K}$, et al Overweight, obesity, and mortality from cancer in a prospectively studied cohort of US adults. N Engl J Med 2003;348(17):1625-38.

4. Althuis MD, Fergenbaum JH, Garcia-Closas $M$, et al. Etiology of hormone receptor-defined breast cancer: a systematic review of the literature. Cancer Epidemiol Biomarkers Prev 2004;13(10):1558-68.

5. Gotzsche PC, Jorgensen KJ. Screening for breast cancer with mammography. Cochrane Database Syst Rev 2013;6:CD001877.

6. Hayes DF, Isaacs C, Stearns V. Prognostic factors in breast cancer: current and new predictors of metastasis. Journal of Mammary Gland Biology and Neoplasia 2001;6(4):37592.

7. Rugo HS. The importance of distant metastases in hormone-sensitive breast cancer. Breast 2008;17(suppl1):S3-8.

8. Ducatma BS, Wang HH. Breast. Chapter 9. In: Cibas ES, Ducatman BS, eds. Cytology: diagnostic principles and clinical correlates. $4^{\text {th }}$ edn. Philadelphia, USA: Elsevier Saunders 2014:233-66.

9. Zhang YJ, Wei L, Li J, et al. Status quo and development trend of breast biopsy technology. Gland surgery 2013;2(1):15-24.

10. Litherland J. The role of needle biopsy in the diagnosis of breast lesions. Breast 2001;10(5):383-7.

11. Lieske B, Ravichandran D, Wright D, et al. Role of fineneedle aspiration cytology and core biopsyin the preoperative diagnosis of screen-detected breast carcinoma. British Journal of Cancer 2006;95(1):62-6.

12. Ellis IO, Pinder SE, Lee AH. Tumors of the breast. $3^{\text {rd }}$ edn. In: Fletcher CD. Diagnostic histopathology of tumors. Philadelphia: Churchill Livingstone 2007;1:903-70.

13. Donegan WL. Tumor related prognostic factors for breast cancer. CA Cancer J Clin 1997;47(1):28-51. 
14. Ahmad Z, Khurshid A, Qureshi A, et al. Breast carcinoma grading, estimation of tumor size, axillary lymph node status, staging, and nottinghamprognostic index scoring on mastectomy specimens. Indian J Pathol Microbiol 2009;52(4):477-81.

15. Chen $S$, Iversen ES, Friebel $T$, et al. Characterization of BRCA1 and BRCA2 mutations in a large United States sample. J Clin Oncol 2006;24(6):863-71.

16. Yang D, Khan S, Sun Y, et al. Association of BRCA1 and BRCA2 mutations with survival, chemotherapy sensitivity, and gene mutator phenotype in patients with ovarian cancer. JAMA 2011;306(14):1557-65.
17. Lindström LS, Karlsson E, Wilking UM, et al. Clinically used breast cancer markers such as estrogen receptor, progesterone receptor, and human epidermal growth factor receptor 2 are unstable throughout tumor progression. JCO 2012;30(21):2601-8.

18. Mechera R, Viehl CT, Oertli D. Factors predicting in-breast tumor recurrence after breast-conserving surgery. Breast Cancer Res Treat 2009;116(1):171-7. 